Article

\title{
An Integrated Approach to Identify Water Resources for Human Consumption in an Area Affected by High Natural Arsenic Content
}

\author{
Giovanna Armiento ${ }^{1}$, Antonella Baiocchi ${ }^{2}$, Carlo Cremisini ${ }^{1}$, Cinzia Crovato ${ }^{1}$, Francesca Lotti ${ }^{2}$, \\ Luca Lucentini ${ }^{3}$, Maurizio Mazzuoli ${ }^{1,2, *}$, Elisa Nardi ${ }^{1}$, Vincenzo Piscopo ${ }^{2}$, Marco Proposito ${ }^{1}$ \\ and Enrico Veschetti ${ }^{3}$
}

1 Agenzia Nazionale per le Nuove Tecnologie, l'Energia e lo Sviluppo Economico Sostenibile, Laboratorio di Biogeochimica Ambientale, Via Anguillarese 301, Rome 00123, Italy;

E-Mails: giovanna.armiento@enea.it (G.A.); carlo.cremisini@enea.it (C.C.); cinzia.crovato@enea.it (C.C.); elisa.nardi@enea.it (E.N.); marco.proposito@enea.it (M.P.)

2 Dipartimento di Scienze Ecologiche e Biologiche, Università degli Studi della Tuscia, Largo Università, Viterbo 01100, Italy; E-Mails: baiocchi@unitus.it (A.B.); f.lotti@unitus.it (F.L.); piscopo@unitus.it (V.P.)

3 Istituto Superiore di Sanità, Viale Regina Elena 299, Rome 00161, Italy;

E-Mails: luca.lucentini@iss.it (L.L.); enrico.veschetti@iss.it (E.V.)

* Author to whom correspondence should be addressed; E-Mail: maurizio.mazzuoli@enea.it; Tel.: +390630486732.

Academic Editor: Yung-Tse Hung

Received: 30 July 2015 / Accepted: 10 September 2015 / Published: 18 September 2015

\begin{abstract}
This study concerns the occurrence of arsenic in the groundwater system of the Cimino-Vico volcanic area (central Italy), different parts of which are currently widely used for local drinking water supply and for irrigation. The system shows a complex groundwater circulation, including a continuous basal aquifer, discontinuous perched aquifers, groundwater flows at high altitude, and local interactions with rising thermal fluids. Data on arsenic contents in 250 water samples from springs and wells and in 68 samples from rock outcrops were measured and combined with already existing information. Results highlight that arsenic concentrations of groundwater are influenced by type of aquifer, groundwater flow path, arsenic content of the aquifer rocks, and interaction with fluids rising from depth. Waters circulating in the Vico volcanics, one of the prominent rock units of the area, have high concentrations of arsenic, both for the basal
\end{abstract}


and the perched aquifers. A large fraction of the waters associated with this rock unit have arsenic contents higher than $10 \mu \mathrm{g} / \mathrm{L}$ (82 percent for basal, 40 percent for perched). In contrast, waters circulating in the Cimino volcanics have lower arsenic contents: 30 percent of the basal and 10 percent of the perched aquifers have arsenic concentrations greater than $10 \mu \mathrm{g} / \mathrm{L}$. Through an integrated approach, including leaching tests to investigate the arsenic behavior concerning the water-rock interaction and a geostatistical modeling of data, it has been possible to identify and tentatively quantify suitable water resources that have arsenic content not exceeding the quality standards for human consumption.

Keywords: arsenic; volcanic aquifer; water-rock interaction; drinkable water; geostatistics; Italy

\section{Introduction}

Arsenic is widely distributed in the environment and volcanic activity is considered one of the main natural sources. Hence, arsenic occurrence in groundwater circulating in volcanic rocks is widespread. This is related to the presence of the element as a minor constituent of volcanic gases and geothermal fluids and to the leaching of rocks containing the element as a minor constituent [1-4]. The presence of arsenic in groundwater of the volcanic areas of central and southern Italy has been documented for about thirty years [5-16]. These studies show that several factors control the arsenic mobility in groundwater, such as water temperature, host-rock composition, water chemistry, and the influence of magma-derived volatiles.

The present study concerns the occurrence of arsenic in groundwater of the Cimino-Vico volcanic area (central Italy), which includes a continuous basal aquifer, discontinuous perched aquifers, groundwater flows at high altitude, and local interactions with rising thermal fluids.

The occurrence of arsenic in groundwater of the Cimino-Vico volcanic area is mainly associated with those fluids of the active hydrothermal system that rise from depth. As a matter of fact the highest arsenic concentrations (from $180 \mu \mathrm{g} / \mathrm{L}$ to $370 \mu \mathrm{g} / \mathrm{L}$ ) were found in the thermal waters. The arsenic concentration in groundwater of the volcanic aquifer of the Cimino-Vico system, widely used for local drinking water supply and for irrigation, is variable from $1 \mu \mathrm{g} / \mathrm{L}$ to $100 \mu \mathrm{g} / \mathrm{L}[17,18]$. The distribution of the geogenic contaminant was explained through the complexity of the hydrostratigraphy, the structural setting of the area, and the related mixing occurring between water circulating in the basal volcanic aquifer and the fluids that rise from depth, all of which characterize the active hydrothermal system. A recently published study [12], still based on chemical analysis of groundwater, has reached the same conclusions.

None of the previous studies analyzes the arsenic distribution and its variability in groundwater taking into account the influence of the characteristics of flow in volcanic aquifers, the incidence of the different types of aquifers and the possibility of a different content of arsenic in the water bearing formations. In the present study: (1) data on arsenic concentration in groundwater are re-examined on the basis of data available in literature and new water samples analyses, (2) each collected water sample has been carefully matched to the pertaining type of aquifer by detailed hydrogeological 
characterization, and (3) the arsenic content of the rocks of the area has been measured and preliminary leaching tests were performed on samples of the most relevant rock types. The goal has been to link the occurrence of the element in groundwater to the host rocks and their hydrogeological properties, and then to deepen knowledge about the influence of the complex hydrogeological system on the arsenic distribution in groundwater in volcanic areas. In other words, the objective is to outline hydrogeologically/geochemically-based criteria to identify areas, aquifers, and the amount of groundwater resources for human consumption in this challenging hydrogeological environment. This integrated approach is essential to address the future options for the management of groundwater resources, especially if one considers that the local demand for drinking water (approximately 170,000 inhabitants) is supplied by groundwater tapped only on the basis of proximity to users, and building expensive and not easily manageable treatment plants.

The same problems also affect other areas of the world characterized by groundwater flow interacting with volcanic rocks (e.g., [19,20]).

\section{Geological and Hydrogeological Framework}

The study area lies between the Tyrrhenian coast and the Apennine chain (Figure 1a). This region contains a series of sedimentary basins whose origins are related to the processes that occurred during the formation of the Apennine chain. In the final stages of the Apennine orogeny, since the Pliocene, an intense volcanic activity affected the region. Accordingly, a strong regional heat flow anomaly $\left(>150 \mathrm{~mW} / \mathrm{m}^{2}\right)$ characterizes the area [21].

Volcanic activity gave rise to the Cimino and Vico complexes (Figure 1a,b). The Cimino complex was active between 1.35 Ma and 0.95 Ma. Effusive and explosive activity gave rise to several domes, with a radial arrangement with respect to the top of Mt. Cimino, that developed along a NW-SE trending fracture and included pyroclastic deposits. Rhyodacitic ignimbrites and domes, as well as latitic and olivine-latitic lavas mainly constitute the products of the volcanic complex [22-24]. The Vico complex consists of a stratovolcano with a central caldera that houses the homonymous Lake (Figure 1b). This volcano was mainly active between $419 \mathrm{ka}$ and $95 \mathrm{ka}$ and developed along a NW-SE elongated graben. Alternating explosive and effusive phases gave rise to several pyroclastic deposits and lava flows, which are phonolitic, tephritic, and trachytic in composition [25-27].

The volcanic rocks are covered and bounded locally by Pleistocene-Holocene continental sediments. The folded and thrusted substratum beneath the Cimino and Vico volcanics consists of different sedimentary rocks: the Pliocene-Pleistocene sedimentary complex, the Upper Cretaceous-Oligocene Flysch and the Triassic-Palaeogene carbonate rocks [28-31].

The structural features of the area are very complex because of neotectonic activity and more recent volcano-tectonic related deformation. Within the study area, faults oriented N-S, E-W, NW-SE, and NE-SW subdivide the deep structures and control the uplift of the volcanic basement [28,31-33].

The Cimino and Vico volcanics constitute a hydrogeological system bounded by the Pliocene-Pleistocene sedimentary complex and Upper Cretaceous-Oligocene Flysch (Figure 2a,b). A continuous basal aquifer and several perched aquifers have been found within the complex hydrostratigraphy, which includes relatively high-permeability units (such as ignimbrites and lava flows) alternating with low-permeability, discontinuous units (such as tuffs and fine pyroclastic deposits). 


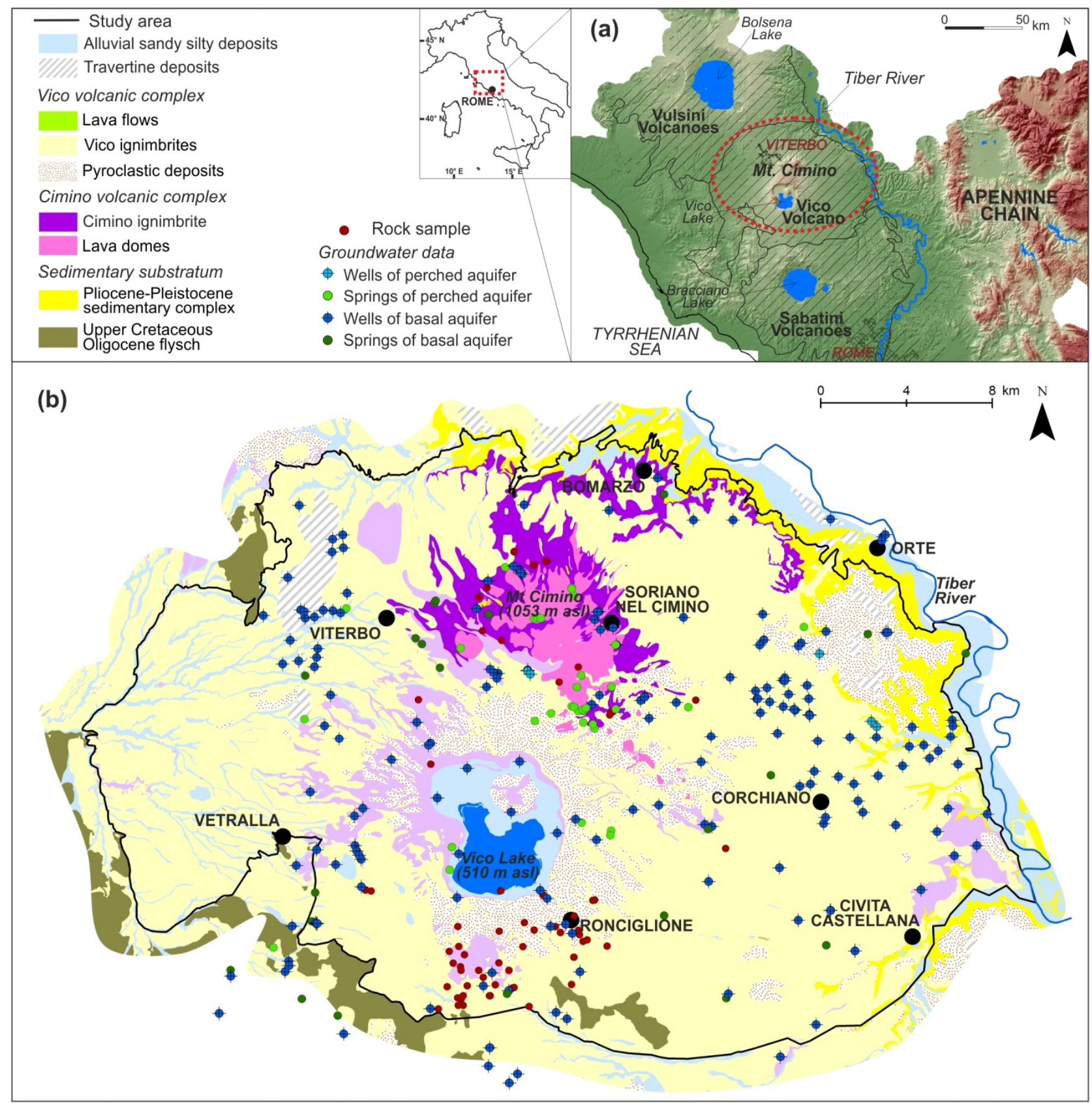

Figure 1. (a) Location of the study area; (b) Geological map of the Cimino-Vico volcanic area (modified from [23]) showing wells, springs, and rock samplings locations.

The basal aquifer, mainly composed of ignimbrites and lavas of the Cimino and Vico volcanoes, is characterized by radially-divergent flow and extends under the entire system (Figure 2a). The basal volcanic aquifer discharges mainly into the streams and springs (generally with flow lower than $0.02 \mathrm{~m}^{3} / \mathrm{s}$ ). Groundwater outflow from the volcanic aquifer towards the alluvial aquifer of the Tiber Valley has been found in the eastern boundary of the system [34].

The perched aquifers are of limited and discontinuous extent, and discharge to several springs located at high elevation and characterized by low flow (generally lower than $0.005 \mathrm{~m}^{3} / \mathrm{s}$ ) (Figure 2a). The origin of these springs is different according to the type of rock: (1) ash deposits and paleosols in 
the pyroclastic fall products, which locally reduce the permeability of the formation constituted by layers of pumice and scoria; (2) consolidated formations of ignimbrites and lava flows having different degree of fracturing and weathering. Several springs are located at the edge of the lava domes of the Cimino volcanic complex. Their discharge of groundwater at high altitude has been interpreted as being due to the presence of dome-impounded groundwater [35].

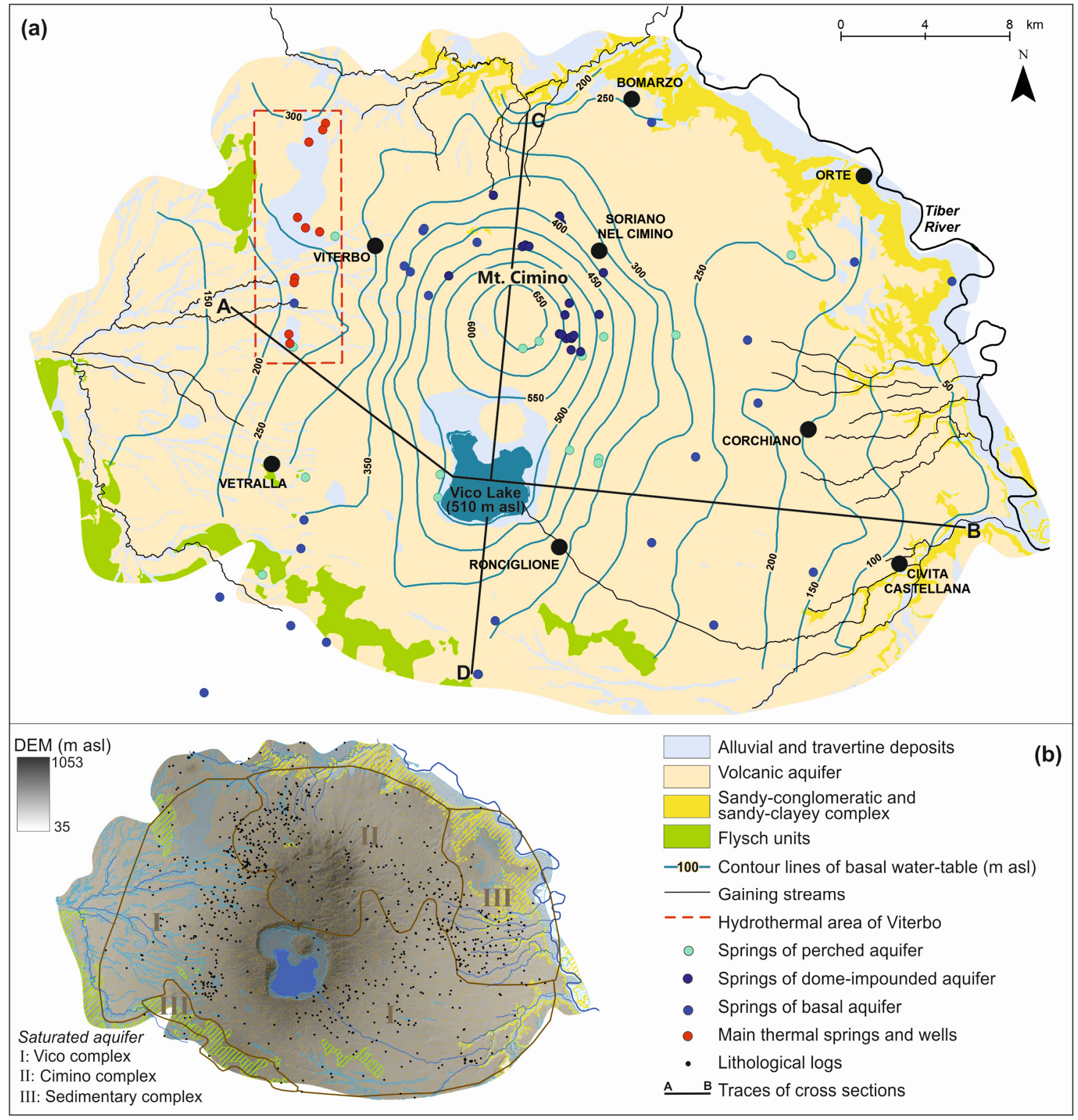

Figure 2. (a) Simplified hydrogeological map of the Cimino-Vico volcanic area (modified from [34]); (b) Map of the saturated aquifer reconstructed through the intersection of the water table with stratigraphic logs. 
The available data on ranges of yield, transmissivity, and storativity, apply to wells, generally of 10-200 $\mathrm{m}$ depth, that are used for public water supply, and for private irrigation and industrial purposes. Values of transmissivity and storativity of these aquifers are typically $10^{-2}-10^{-6} \mathrm{~m}^{2} / \mathrm{s}$ and $10^{-2}-10^{-3} \mathrm{~m}^{2} / \mathrm{s}$, respectively. The mean groundwater yield of the system has been estimated between $5 \mathrm{~m}^{3} / \mathrm{s}$ and $7 \mathrm{~m}^{3} / \mathrm{s}$. The discharge has been estimated at approximately $2.0 \mathrm{~m}^{3} / \mathrm{s}$ into the streams and springs, $2.3 \mathrm{~m}^{3} / \mathrm{s}$ as flow towards adjacent aquifers, and $1.5 \mathrm{~m}^{3} / \mathrm{s}$ pumped from numerous scattered wells mainly for drinking and irrigation purposes [34].

In the western part of the system, thermal waters emerge from springs and deep wells (Figure 2a). These waters are considered to be due to rising of deeper groundwater through circuits into the sedimentary basement of the volcanics, where the basement is locally uplifted, fractured, and faulted, and a strong heat flow anomaly exists. The yield of these deeper groundwater circuits for the hydrothermal area of Viterbo is at least $0.1 \mathrm{~m}^{3} / \mathrm{s}$ [36-38].

The hydrogeological conceptual model described above is summarized in Figure 3, where the different flow paths are schematically shown. The waters which outflow from springs of the perched aquifer and dome-impounded groundwater are characterized by limited length of the flow path (in the order of a few kilometers), since they are located at higher altitudes, closer to the main recharge area. In contrast, the waters of the basal aquifer have longer paths in volcanic rocks (in the order of some tens of kilometers); even longer paths characterize the thermal waters that circulate in the sedimentary substrate of volcanics $[17,34,36]$. Chemical characteristics of groundwater are coherent with this hydrogeological model. Thermal waters are of the sulfate alkaline earth type, have temperatures between $40{ }^{\circ} \mathrm{C}$ and $62{ }^{\circ} \mathrm{C}$, electrical conductivity between $2700 \mu \mathrm{S} / \mathrm{cm}$ and $3400 \mu \mathrm{S} / \mathrm{cm}$, tritium concentrations between $2 \mathrm{TU}$ and $5 \mathrm{TU}$, and high gas content, e.g., $\mathrm{CO}_{2}$ and $\mathrm{H}_{2} \mathrm{~S}$ up to $994 \mathrm{mmol} / \mathrm{mol}$ and $0.99 \mathrm{mmol} / \mathrm{mol}$ in dry gas, respectively [36-39]. In contrast, the waters of the perched and basal aquifers comprise fresh, cold waters of the bicarbonate alkaline earth type (electrical conductivity generally between $100 \mu \mathrm{S} / \mathrm{cm}$ and $1000 \mu \mathrm{S} / \mathrm{cm}$, temperature generally between $13{ }^{\circ} \mathrm{C}$ and $20{ }^{\circ} \mathrm{C}$, tritium concentrations between $8 \mathrm{TU}$ and $11 \mathrm{TU}$ ). In the hydrothermal area of Viterbo, the reduced thickness of the low-permeability layer that divides the basal aquifer from the deeper aquifer and its hydraulic heterogeneity give rise to a flow between the two overlapping aquifers and then to mixing between cold and thermal waters [17,36-39]. All waters exhibit $\delta^{18} \mathrm{O}$ and $\delta^{2} \mathrm{H}$ values in a limited range ( $-5.6 \%$ to $-7.2 \%$ and $-34 \%$ o to $-44 \%$, respectively) and fall on the meteoric water lines, suggesting the presence of a common recharge area [36]. 


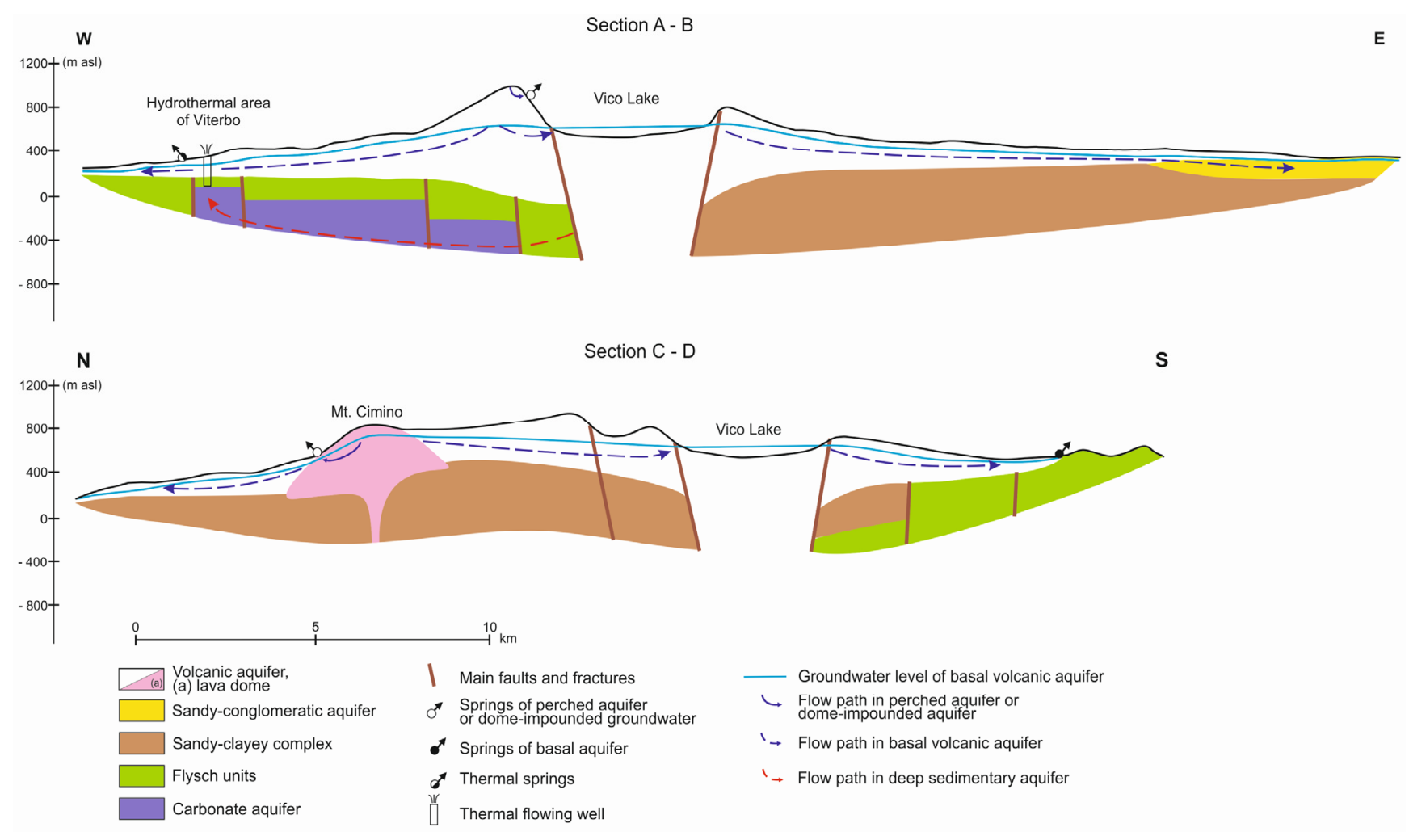

Figure 3. Hydrogeological cross-sections (referred to A-B and C-D lines in Figure 2a) through the Cimino and Vico volcanoes showing different flow paths.

\section{Materials, Data and Methods}

Information considered to conduct the present study included previously available chemical analyses of groundwater, hydrogeological and spatial context of sampled waters, analyses of the bulk arsenic contents of rocks, and tests on leaching of arsenic from the rocks to specific aqueous solutions.

Numerous data about the arsenic contents of groundwater in the study area and its surroundings are available in the literature $[5,16,17,36]$. Other unpublished data were acquired by the Italian National Institute of Health (ISS), by the local water management company (Talete SpA, Viterbo, Italy), and by the regional environmental protection agency (ARPA Lazio, Rieti, Italy). Additional analyses were performed specifically for the present study: in this case the wells were first purged, in order to remove stagnant water from the pipes. This was done at low flow rate to ensure a reduced drawdown in the well. Then, groundwater samples were collected in polyethylene tubes, after being filtered through $0.45 \mu \mathrm{m}$ Teflon filters. They were then acidified to $\mathrm{pH}<2$ with $\mathrm{HNO}_{3}$ (BDH-Aristar grade). All the samples were immediately placed into storage at $4{ }^{\circ} \mathrm{C}$ and kept at that temperature until being analyzed for arsenic by ICP-MS (Perkin-Elmer ELAN 6100, Waltham, MA, USA).

Data, from both literature sources and from the present study analyses, were evaluated for inclusion in the dataset according to the following requirements: (1) fresh waters (i.e., the thermal waters were not considered), (2) good hydrogeological characterization of source, and (3) good comparability and accuracy of sampling and analytical techniques (i.e., ICP-MS, ET-AAS and HG-AAS).

The data considered in this study are: 32 analyses by Vivona et al. [16] conducted in 2002 and 2003, 48 analyses by Angelone et al. [17] conducted in 2007, 100 analyses by Achene et al. [5] 
conducted in 2007 and 2008, 125 analyses by ISS conducted in 2007 and 2008, 93 analyses by Talete SpA conducted in 2009-2011, 19 analyses by ARPA Lazio conducted in 2005-2013, 24 analyses by Baiocchi et al. [36] conducted in 2009 and 32 analyses performed for the present study.

Some sources are included in more than one sampling campaign and, hence, were analyzed by the same laboratory in different periods, or by different laboratories. In the case of multiple determinations, the mean values were adopted. Some anomalous values were identified as outliers and discarded. The dataset consists of a total of 250 sources (Figure 1) including wells and springs supplying water for drinking (58 springs and 97 wells), domestic and irrigation purposes ( 9 springs and 86 wells).

Springs and wells were hydrogeologically characterized by type and lithological composition of the aquifer. This characterization was performed enquiring the Italian National Institute for Environmental Protection and Research (ISPRA) database [40] for boreholes and wells, together with the scientific literature and technical documents available for the study area. The stratigraphy, aquifer rocks, and water levels of more than 800 boreholes and wells were examined one by one in order to define the geological and hydrogeological context of each water source of the dataset (Figures 2 and 3). Depths of the boreholes range from tens to hundreds of meters. Water samples were first classified as being from perched or basal aquifers, comparing the height of spring and water level of well with the available basal piezometric surface [34,41], and considering the flow rates of the springs, depths of the wells and salinity of waters. Successively, the waters sampled were attributed to the Cimino or Vico volcanic complex, based on the saturated aquifer that feeds the springs or that is intercepted by wells (Figure 2b). A third subdivision included stratigraphic logs, local hydrogeological settings, rock compositions, type of porosity (primary or secondary porosity) which allowed the distinction into different classes of aquifer: Cimino Ignimbrite (CI), Lava Dome (LD), Lava Flows (LFV), Vico Ignimbrites (VI), Non-Welded and Partially Welded Pyroclastic Deposits (NWV), Sedimentary (S) (Table 1).

Table 1. Classes of aquifers and main characteristics.

\begin{tabular}{cccc}
\hline Class of Aquifer & $\begin{array}{c}\text { Volcanic/Sedimentary } \\
\text { Complex }\end{array}$ & $\begin{array}{c}\text { Hydrogeological } \\
\text { Properties }\end{array}$ & Rock Composition \\
\hline Cimino Ignimbrite (CI) & Cimino Volcano & Secondary porosity & $\begin{array}{c}\text { Quartz-latitic } \\
\text { Latitic, olivine-latitic, } \\
\text { alkali-trachytic }\end{array}$ \\
Lava dome (LD) & Cimino Volcano & Secondary porosity & Trachytic, tephritic, phonolitic- \\
& Vico Volcano & Secondary porosity & $\begin{array}{c}\text { Trachytic, phonolitic-tephritic, } \\
\text { tephritic-phonolitic, }\end{array}$ \\
Vico ignimbrites (VI) & Vico Volcano & Primary and secondary & trachytic-phonolitic \\
Non-welded and partially & & porosity & Trachytic, tephritic, phonolitic \\
welded pyroclastic deposits & Vico Volcano & Primary porosity & \\
(NWV) & Pleistocene formations & Primary and secondary & Sands, conglomerates, sandstones, \\
& Upper Cretaceous- & pligocene Flysch & calcarenites, marly limestone
\end{tabular}


Since an aquifer can be considered a two component system, the bulk chemical compositions of the aquifer rocks were measured, most specifically of the main rock types of the study. The analyses included arsenic contents. A total of 68 samples was collected from outcrops around the Mt. Cimino and Vico Lake, and chemically analyzed (Figure 1).

Arsenic concentrations of rock samples were measured by ICP-MS (Perkin-Elmer ELAN 6100, Waltham, MA, USA) after acid dissolution of the powdered samples and performed according to the EPA 3052 procedure [42] using $\mathrm{HNO}_{3}, \mathrm{HF}$, and $\mathrm{H}_{2} \mathrm{O}_{2}$ as the reagent mixture.

Laboratory experiments have also been carried out to better understand the interactions occurring between the aqueous and solid phases of the system. For each sample, leaching tests were performed as follows: $5 \mathrm{~g}$ of rock sample, previously ground to $<100 \mu \mathrm{m}$, were added to $95 \mathrm{~mL}$ of deionized water $\left(18.2 \mathrm{M} \Omega \mathrm{cm}\right.$ at $25^{\circ} \mathrm{C}$; solid/liquid ratio 1/20) in polyethylene bottles and placed in an end-over-end shaker. Deionized water was used to obtain results comparable with the most extended experiments in the literature [43-45]. Independent experiments were conducted for specific times $(0.25 \mathrm{~h}, 0.5 \mathrm{~h}, 1 \mathrm{~h}$, $3 \mathrm{~h}, 5 \mathrm{~h}, 12 \mathrm{~h}, 24 \mathrm{~h}, 48 \mathrm{~h}, 72 \mathrm{~h}$, and $168 \mathrm{~h}$ ) at room temperature. After shaking, the samples were centrifuged for $10 \mathrm{~min}$ at $1500 \times \mathrm{g}$ and the supernatant was filtered using Millipore $0.45 \mu \mathrm{m}$ filters. $\mathrm{HNO}_{3}$ was added to the filtered samples to bring the extracted solution to a total acidity of $1 \%$ and analyses of arsenic were carried out. Moreover, the $\mathrm{pH}$ of the leachate was measured. For each sample, the mean value of triplicate experiments was considered; the coefficient of variation (\%) at every time of the leaching test was always lower than $10 \%$.

All of the maps, information, and data were organized within a geodatabase for further processing in different GIS environments (mainly ESRI ArcMap and SagaGIS). To examine arsenic spatial distribution, deterministic methods (Linear Triangulation, Inverse Distance to Power and Polynomial Interpolation) and geostatistical techniques (Simple, Ordinary, Universal and Disjunctive Kriging) were applied in association with the fitting of the experimental semivariogram. Goodness of the fit was checked in each case by means of "leave-one-out" cross-validation. The procedure consists in employing a single observation as the validation datum, and the remaining observations as the training data. This is repeated such that each observation in the dataset is used once as the validation data, and finally a scatter plot is produced with measured versus estimated data. Comparison between different methods, and different settings of the same method, can be performed considering the root-mean-square error (RMSE) of the scatterplot. In general the geostatistical approach gave better results if compared to the deterministic ones, in particular Ordinary Kriging (OK) [46]. The OK was applied trying different theoretical semivariogram models and different settings of the method. Limits to the OK application lie in the heterogeneity of the sample population and in the presence of interferences given by variables which are not only linked to the spatial distribution. A further qualitative geostatistical approach was tested with Disjunctive Kriging (DK) $[47,48]$ to calculate the probabilities that the arsenic concentration exceeded a threshold. In case of OK original data were log-transformed to obtain a normal distribution; in case of DK the Hermite polynomials transformation was applied [47,48]. In both cases, calibration of the semivariogram model and its parameters was performed to obtain the lower RMSE in cross-validation. The semivariogram which better fitted the transformed variable was used in OK and DK, a binary indicator was set in DK according to the threshold, and the probability of exceeding the threshold itself was estimated. 


\section{Results}

The results are reported with reference to the hydrogeological characterization of the water sampled, the distribution of arsenic in groundwater of the basal aquifer, and the analyses conducted on the rocks and the leaching tests.

\subsection{Hydrogeological Characterization of the Water Sampled}

A total of 250 sources were considered for the arsenic content in groundwater. All waters concerned are $\mathrm{Ca}-\mathrm{HCO}_{3}$ type with temperature from $10{ }^{\circ} \mathrm{C}$ to $24{ }^{\circ} \mathrm{C}, \mathrm{pH}$ from 6.2 to 8.3 and electrical conductivity from $126 \mu \mathrm{S} / \mathrm{cm}$ to $1,324 \mu \mathrm{S} / \mathrm{cm}$. Among these parameters, the most sensitive parameter for the different sampled waters is the electrical conductivity (EC).

The first hydrogeological characterization concerned the type of aquifer, i.e., basal or perched: water samples of 208 sources were attributed to the basal aquifer and 42 to the perched aquifers. For the Cimino volcano, samples from springs and shallow wells located at the edge of the lava domes (Figures 1 and 2) were considered to be related to dome-impounded groundwater and qualitatively associated with the perched aquifers, even if hydrogeologically connected to the basal aquifer (Figure 3). Nevertheless, the proximity of springs and wells to the recharge area and the low EC of their waters were interpreted as related to a reduced length of groundwater circuits, such as those that typically characterize the perched aquifers. Then, springs and wells were hydrogeologically characterized according to their association with different volcanic or sedimentary complexes and classes of aquifer (Table 1). The classification was possible for 245 of the total of 250 sources with reference to the different complexes (i.e., Cimino, Vico, and sedimentary complexes) and for 236 of the total of 250 with reference to the classes of aquifer.

A first representation of the arsenic content in groundwater is reported in the cumulative frequency diagram of Figure 4, which comprises all data for springs and wells according to their classification into basal or perched aquifer (including dome-impounded groundwater). Lower values and a narrow range of arsenic content characterize the perched aquifers: approximately $74 \%$ of the water samples have an arsenic content lower than $10 \mu \mathrm{g} / \mathrm{L}$. For the basal aquifer, arsenic concentrations have a wider range of values and approximately $60 \%$ exceed $10 \mu \mathrm{g} / \mathrm{L}$, i.e., the permissible value for human consumption [49]. The EC values range from $126 \mu \mathrm{S} / \mathrm{cm}$ to $565 \mu \mathrm{S} / \mathrm{cm}$ for the perched aquifers, and from $134 \mu \mathrm{S} / \mathrm{cm}$ to $1324 \mu \mathrm{S} / \mathrm{cm}$ for the basal aquifer.

Since most waters were sampled from volcanic rocks of the Cimino and Vico complexes, statistics for the two volcanic complexes were computed. The EC values range from $126 \mu \mathrm{S} / \mathrm{cm}$ to $459 \mu \mathrm{S} / \mathrm{cm}$ for the waters circulating in the Cimino volcanics, and from $185 \mu \mathrm{S} / \mathrm{cm}$ to $1027 \mu \mathrm{S} / \mathrm{cm}$ for those of the Vico volcanics. The cumulative frequency distributions of arsenic in groundwater samples are shown in Figure 5 for water samples from basal and perched (including dome impounded) aquifers in each of the two volcanic complexes. Waters circulating in the Vico volcanics show higher values of arsenic and a wider range; for both the basal aquifer and the perched/dome-impounded aquifers a high percentage of the sampled waters has an arsenic content higher than $10 \mu \mathrm{g} / \mathrm{L}(82 \%$ and $40 \%$, respectively). Waters circulating in the Cimino volcanics show lower arsenic content: about $70 \%$ and 
$90 \%$ of the sampled waters have values lower than $10 \mu \mathrm{g} / \mathrm{L}$, for the basal and perched/dome-impounded aquifers, respectively.

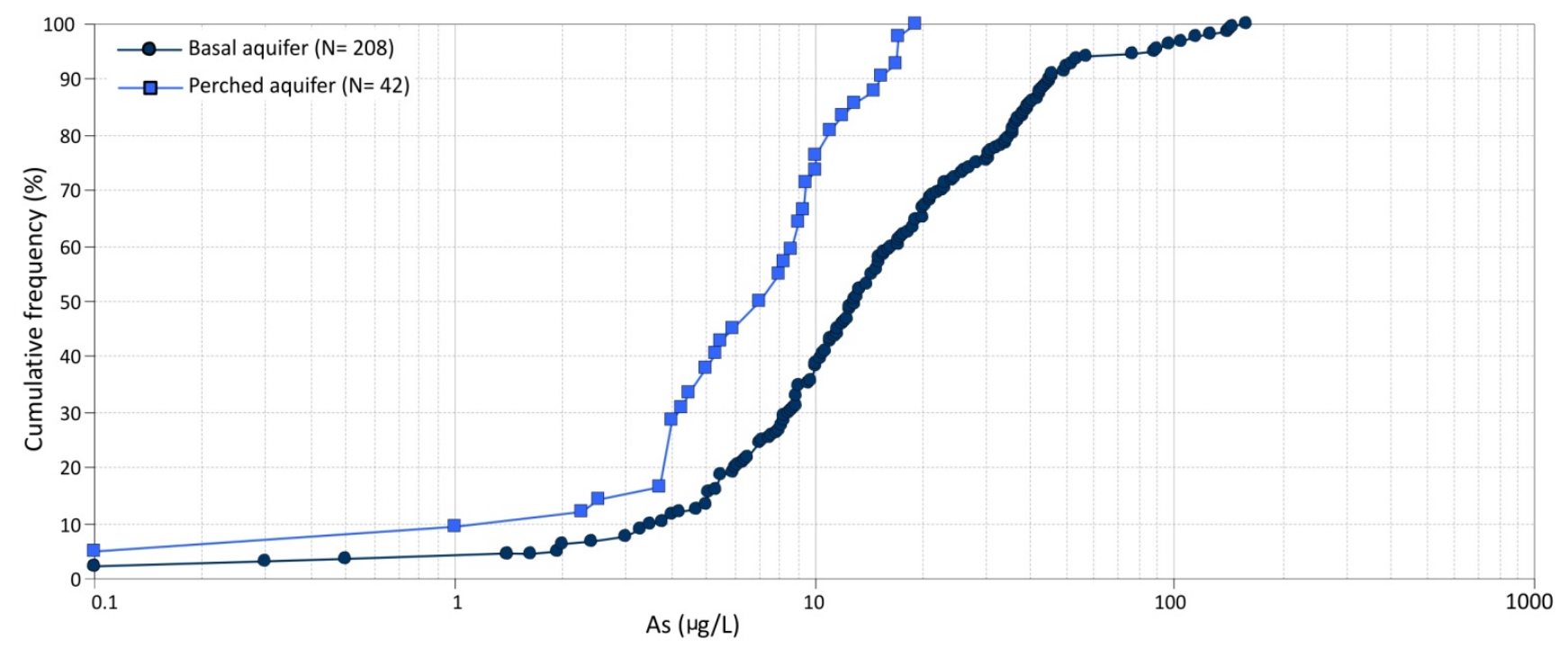

Figure 4. Cumulative frequency plots of arsenic concentrations in groundwater of basal and perched/dome-impounded aquifers.

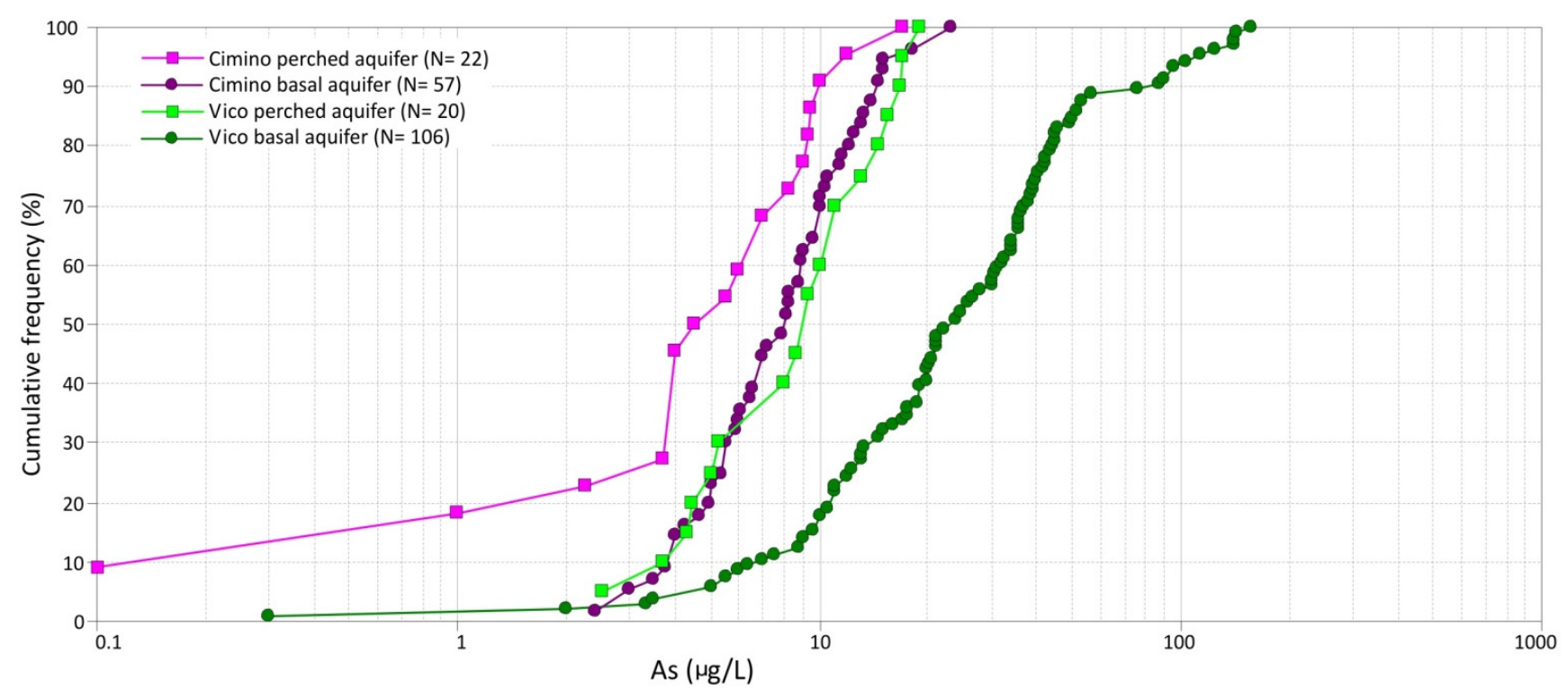

Figure 5. Cumulative frequency plots of arsenic concentrations in groundwater of the Cimino and Vico volcanic complexes.

Arsenic content in groundwater for different classes of aquifer (regardless of the distinction between basal and perched/dome-impounded) is shown in Figure 6: lower values and a limited variability characterize the CI and LD classes of aquifer of the Cimino volcanic complex, higher values characterize the different classes of aquifer related to the Vico volcanic complex (LFV, VI and NWV). Regarding the water samples attributed to the sedimentary class of aquifer (characterized by waters with EC from $207 \mu \mathrm{S} / \mathrm{cm}$ to $1324 \mu \mathrm{S} / \mathrm{cm}$ ), it should be stressed that they were mainly collected in the eastern sector of the hydrogeological system, where the saturated aquifer corresponds to 
groundwater circulating in Pleistocene conglomerates and sands that constitute the local substratum of volcanic complexes, laterally, and vertically influenced by water flow within the volcanics (Figures 1-3).

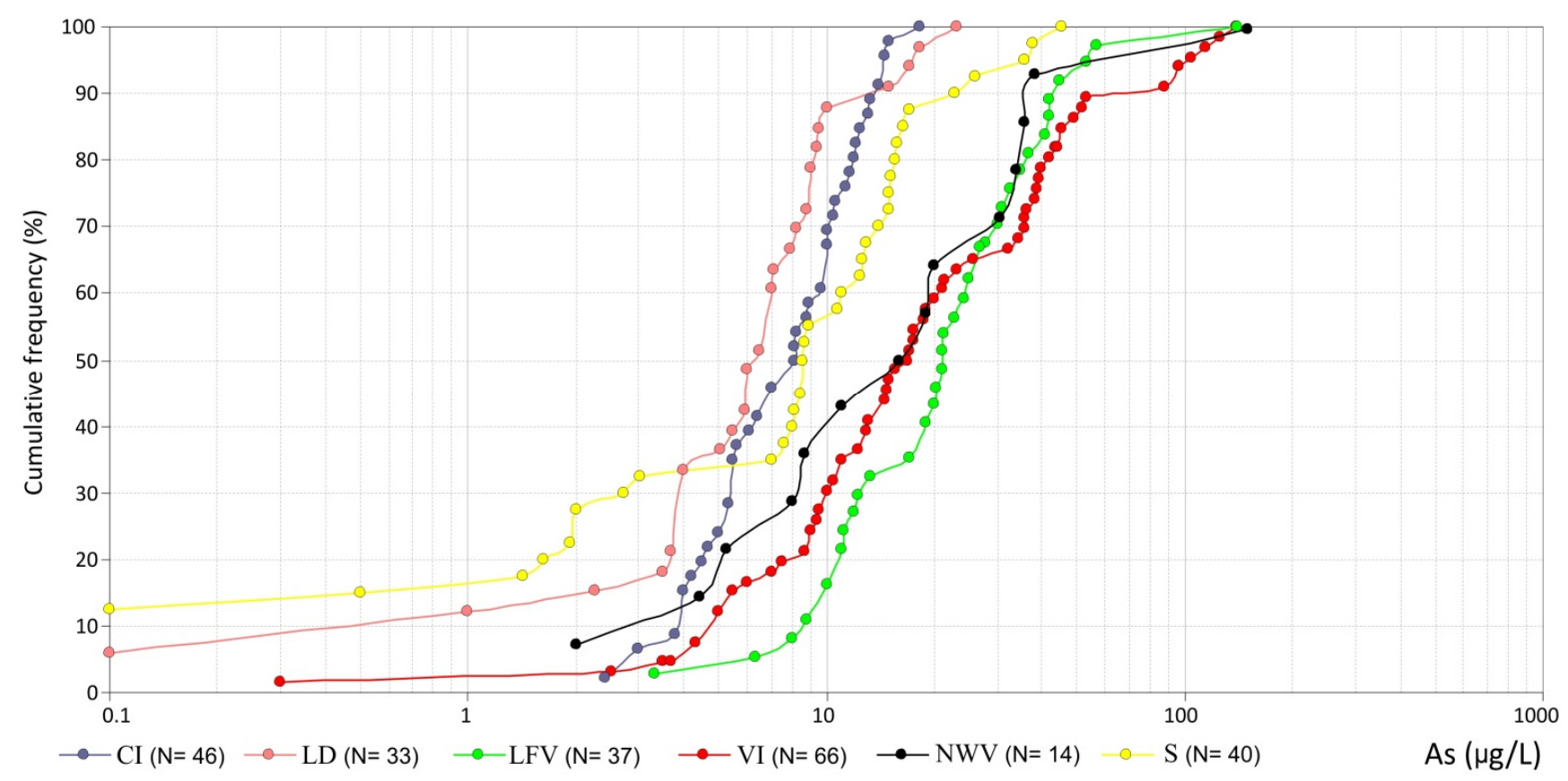

Figure 6. Cumulative frequency plots of arsenic concentrations for the different classes of aquifer.

For sources with more samplings in the period 2002-2014, the observed variation in the arsenic content was generally lower than $20 \%$. For springs fed by the perched aquifers with monthly samplings in the period 2005-2013, a preliminary cross-correlation with the precipitation data showed a decrease in the arsenic content after rainy periods. The absence of a monitoring program and the available data do not allow the identification of a clear seasonal and/or long term variability of As content.

\subsection{Distribution of Arsenic in Groundwater of the Basal Aquifer}

Data on the arsenic content in groundwater of the basal aquifer were analyzed to obtain a map of its areal distribution. It was not possible to reconstruct maps of the arsenic distribution in groundwater of the perched aquifers, due to their reduced spatial continuity.

The high number of factors influencing the arsenic content in groundwater of the basal aquifer and the presence of different classes of aquifer are reflected in the irregular right-skewed distribution of the dataset (Figure 7a). The skewness of the distribution almost disappears when arsenic concentration values are log-transformed, but a highly tailed shape can still be noted in the QQ-Plot of Figure $7 \mathrm{~b}$.

The log-transformed data were geostatistically processed considering the basal aquifer and the dome-impounded sources that are connected to it (e.g., the springs of the Mt. Cimino, Figures 2 and 3).

In a first version of the Ordinary Kriging (OK1), the experimental semivariogram of the log-transformed data was fitted to an isotropic exponential model with maximum lag distance of $10 \mathrm{~km}$, partial sill $0.45 \log _{10} \mu \mathrm{g} / \mathrm{L}$ and nugget variance $0.4 \log _{10} \mu \mathrm{g} / \mathrm{L}$. The nugget variance $(i . e ., 2.5 \mu \mathrm{g} / \mathrm{L})$ was set on the basis of the short distance variation of arsenic concentration (variability inside a radius of $100 \mathrm{~m}$ plus seasonal and vertical variation in the same point), while partial sill and maximum lag distance were iteratively adjusted according to the lower error obtained in the cross-validation. The 
error distribution gave evidence of a failure of the kriging prediction for the highest values of arsenic (Figure 8a), where hydrothermal fluids that rise from the deep aquifer strongly affect the basal aquifer [17,36]. A second version of the OK (OK2) was therefore performed grouping all data with concentrations equal to or higher than $30 \mu \mathrm{g} / \mathrm{L}$, which allowed to obtain a better cross-validation fit in the range $0-30 \mu \mathrm{g} / \mathrm{L}$ (Figure $8 \mathrm{~b}$ ).
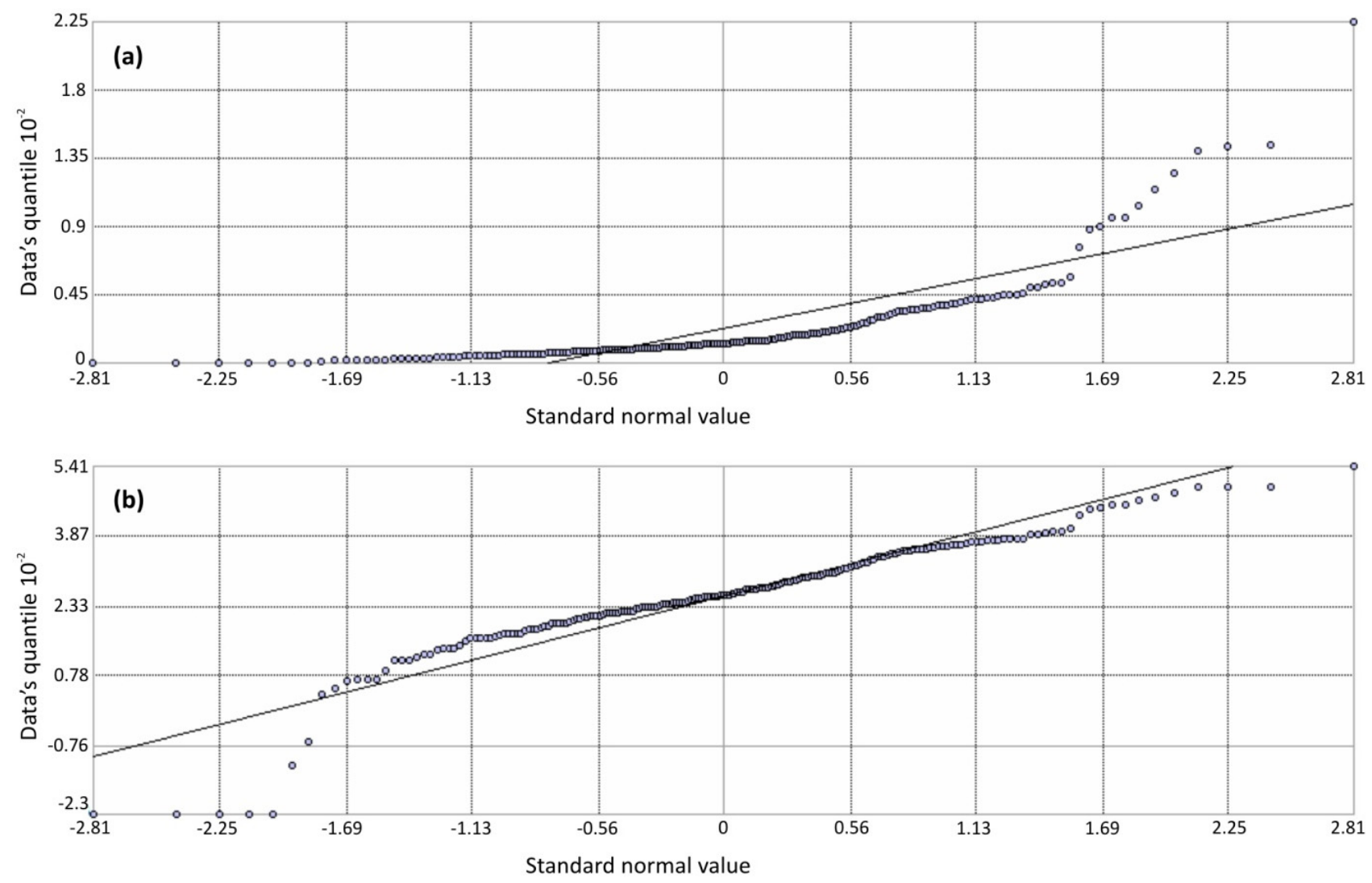

Figure 7. QQ-Plot of the (a) original data and (b) log-transformed data of the basal aquifer.

The settings that gave the lower prediction error and cross-validation results are shown in Table 2 and the resulting maps are shown in Figure 8.

Disjunctive Kriging (DK) was also applied to data transformed through Hermite polynomials, and the probabilities that the arsenic concentration exceeded two thresholds $(10 \mu \mathrm{g} / \mathrm{L}$ and $30 \mu \mathrm{g} / \mathrm{L})$ was estimated. The parameters of the method were iteratively adjusted to reach a minimum RMSE value in cross-validation; results are reported in Table 2 and the probability maps relative to the thresholds of $10 \mu \mathrm{g} / \mathrm{L}$ (DK1) and $30 \mu \mathrm{g} / \mathrm{L}$ (DK2) are shown in Figure 9.

Results of the geostatistical analyses show how difficult it is to capture local spatial variability (Table 2). Results of prediction maps (OK) can reach a relatively low RMSE of $5.98 \mu \mathrm{g} / \mathrm{L}$, only flattening the values above $30 \mu \mathrm{g} / \mathrm{L}$. In the case of the DK, the uncertainty linked to the local variability is taken into account with effects on the probabilities of exceeding the threshold. For example, if a very high value of arsenic is located nearby a low value, in the interpolation with the OK this would cause an increase of the RMSE of cross-validation; in the case of the DK the presence of this hotspot will instead produce the effect to generate a higher probability of exceeding the threshold. 

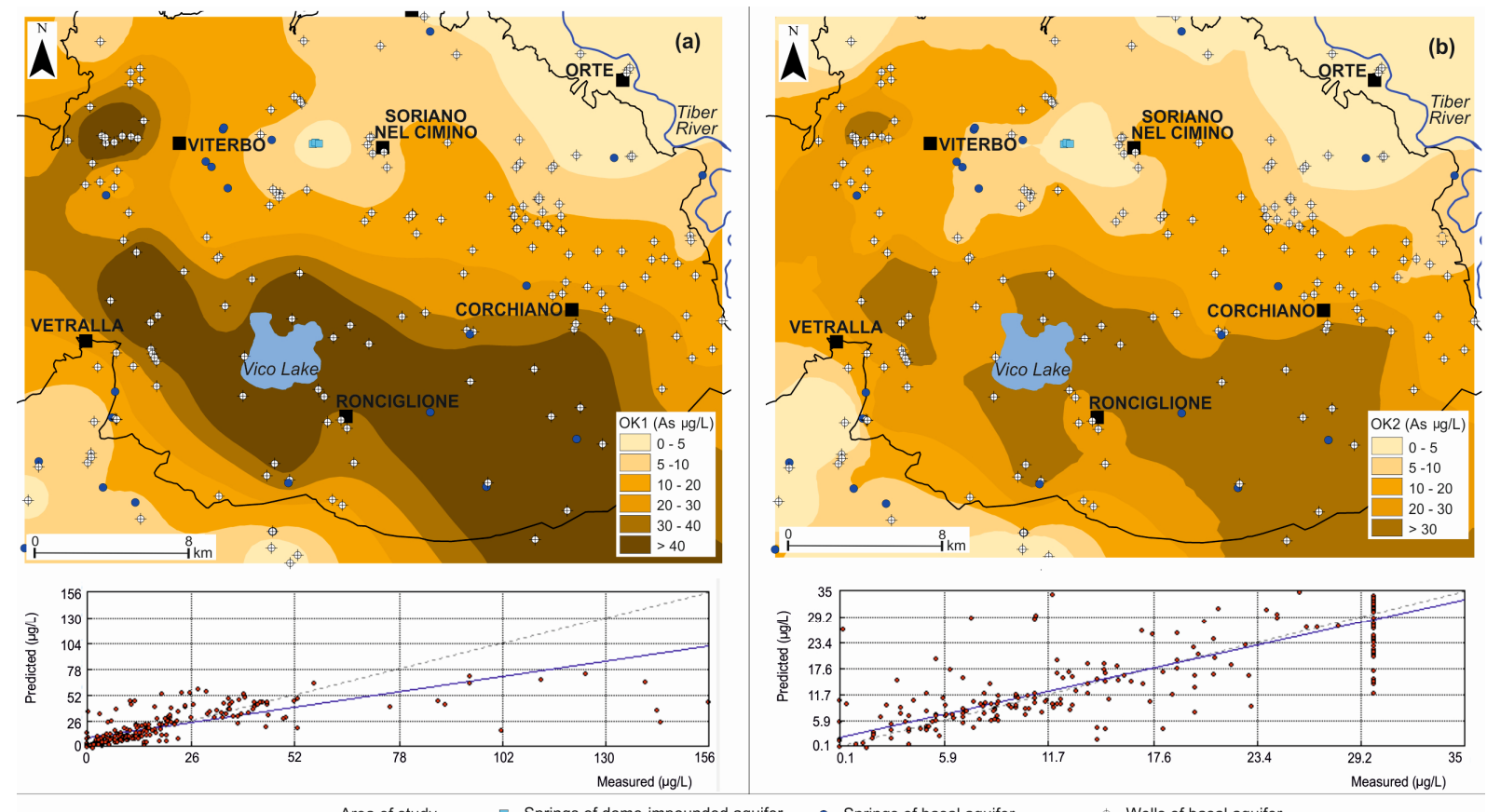

Figure 8. (a) Ordinary Kriging (OK1) of the entire basal aquifer dataset and cross-validation graph; and (b) Ordinary Kriging (OK2) with concentrations $\geq 30 \mu \mathrm{g} / \mathrm{L}$ grouped and cross-validation graph.

Table 2. Summary of the Kriging settings and cross-validation results.

\begin{tabular}{|c|c|c|c|c|}
\hline Settings of the Method & OK1 & OK2 & DK1 & DK2 \\
\hline Type of kriging & Punctual & Punctual & Punctual & Punctual \\
\hline Number of data & 211 & 211 & 211 & 211 \\
\hline Type of map & Prediction map & Prediction map & Probability map & Probability map \\
\hline Threshold $(\mu \mathrm{g} / \mathrm{L})$ & - & - & 10 & 30 \\
\hline Calibrated parameters & OK1 & $\mathrm{OK} 2$ & DK1 & DK2 \\
\hline $\begin{array}{l}\text { Best fit Variogram model and } \\
\text { transformation }\end{array}$ & $\begin{array}{c}\text { Exponential } \\
\text { Log transformed } \\
\text { variable }\end{array}$ & $\begin{array}{c}\text { Exponential } \\
\text { Log transformed } \\
\text { variable }\end{array}$ & $\begin{array}{l}\text { Exponential } \\
\text { Hermite polynomials } \\
\text { transformed variable }\end{array}$ & $\begin{array}{l}\text { Exponential } \\
\text { Hermite } \\
\text { polynomials } \\
\text { transformed } \\
\quad \text { variable }\end{array}$ \\
\hline Max number of neighbors & 20 & 20 & 20 & 20 \\
\hline Max lag distance (km) & 10 & 9 & 8 & 8 \\
\hline Partial sill $\left(\log _{10} \mu \mathrm{g} / \mathrm{L}\right)$ & 0.45 & 0.50 & 1.257 & 1.264 \\
\hline Nugget $\left(\log _{10} \mu \mathrm{g} / \mathrm{L}\right)$ & 0.4 & 0.03 & 0.4 & 0.4 \\
\hline $\begin{array}{c}\text { Final Cross-Validation } \\
\text { statistics }\end{array}$ & OK1 & OK2 & DK1 & DK2 \\
\hline Mean of residuals $(\mu \mathrm{g} / \mathrm{L})$ & 0.392 & 0.378 & -0.010 & -0.006 \\
\hline $\operatorname{RMSE}(\mu \mathrm{g} / \mathrm{L})$ & 19.91 & 5.980 & 0.366 & 0.322 \\
\hline Average Standard Error $(\mu \mathrm{g} / \mathrm{L})$ & 22.98 & 9.069 & 0.416 & 0.363 \\
\hline Mean standardized $(\mu \mathrm{g} / \mathrm{L})$ & 0.009 & -0.012 & -0.014 & -0.016 \\
\hline Standardized RMSE & 0.857 & 0.854 & 0.888 & 0.876 \\
\hline
\end{tabular}

Notes: OK1: Ordinary Kriging 1; OK2: Ordinary Kriging 2; DK1: Disjunctive Kriging 1; DK2: Disjunctive

Kriging 2; RMSE: root mean square error. 


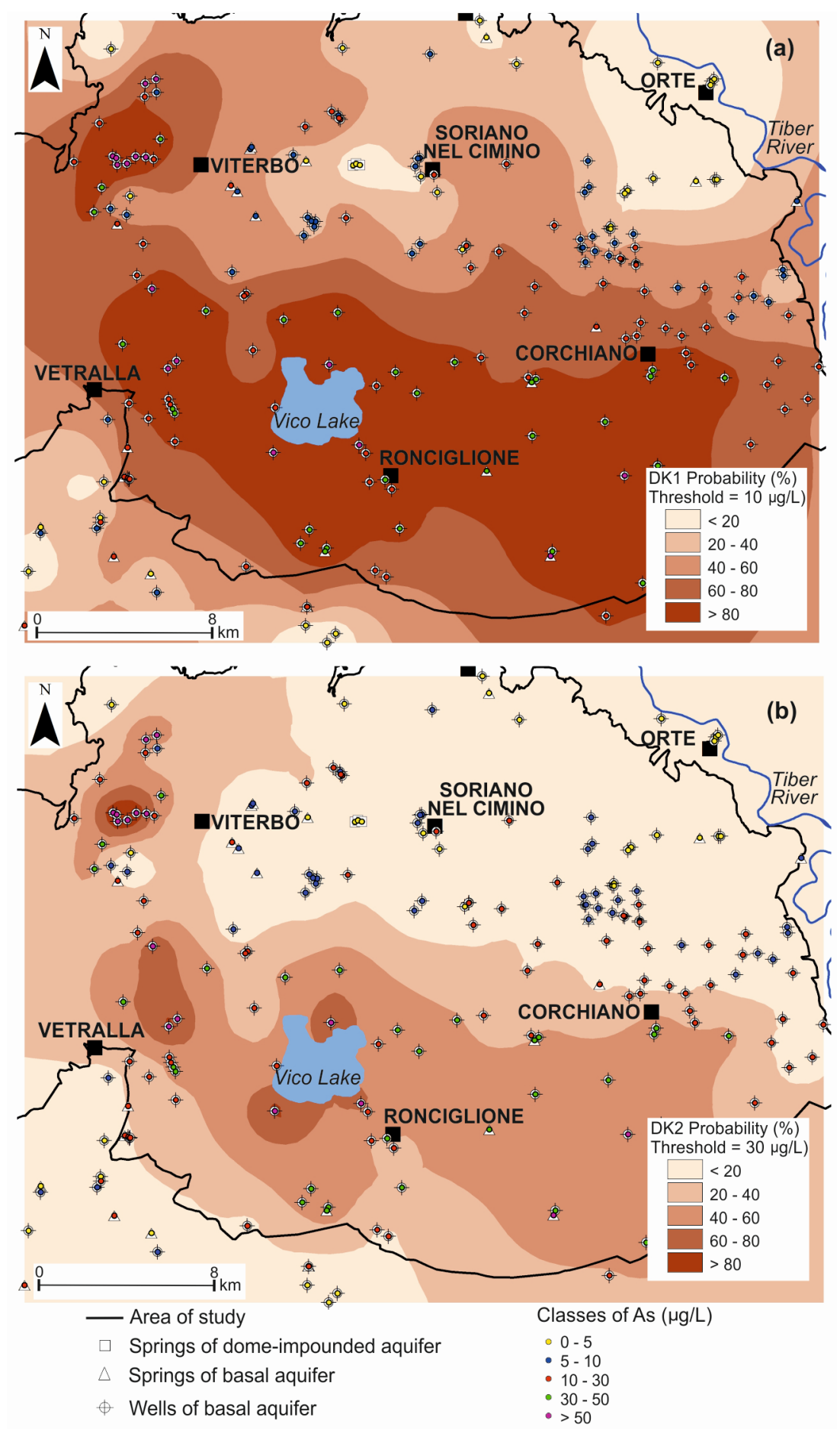

Figure 9. (a) Disjunctive Kriging (DK1) with threshold $=10 \mu \mathrm{g} / \mathrm{L}$; and (b) disjunctive Kriging (DK2) with threshold $=30 \mu \mathrm{g} / \mathrm{L}$.

\subsection{Rock Analyses and Leaching Tests}

The results concerning arsenic content in the rocks are reported in Table 3. The data show that Vico volcanics have a higher content of arsenic (average $61 \mathrm{mg} / \mathrm{kg}$ ) and a wider range compared to Cimino rocks (average $27 \mathrm{mg} / \mathrm{kg}$ ). 
Table 3. Arsenic concentrations in rocks ( $\mathrm{SD}=$ standard deviation).

\begin{tabular}{cccccc}
\hline Rock Type & No. of Samples & Min (mg/kg) & Max (mg/kg) & Mean (mg/kg) & SD (mg/kg) \\
\hline CI & 11 & 14 & 42 & 29 & 7 \\
LD & 2 & 12 & 17 & 15 & 4 \\
Cimino total & 13 & 12 & 42 & 27 & 9 \\
LFV & 12 & 18 & 81 & 58 & 24 \\
VI & 35 & 9 & 166 & 66 & 111 \\
NWV & 8 & 23 & 57 & 42 & 11 \\
Vico total & 55 & 9 & 166 & 61 & 38 \\
\hline
\end{tabular}

The aim of the leaching tests was a preliminary evaluation of the possible arsenic release due to water-rock interaction. The results of leaching tests carried out on a VI rock sample and a CI rock sample, both with similar arsenic contents of about $30 \mathrm{mg} / \mathrm{kg}$, show that the release of arsenic in steady state conditions is very small: the fractions of total bulk arsenic in the whole rock released from VI and CI samples are about $0.8 \%$ and $0.4 \%$, respectively, after $168 \mathrm{~h}$. The trends of release of the two samples are similar, as shown in Figure 10.

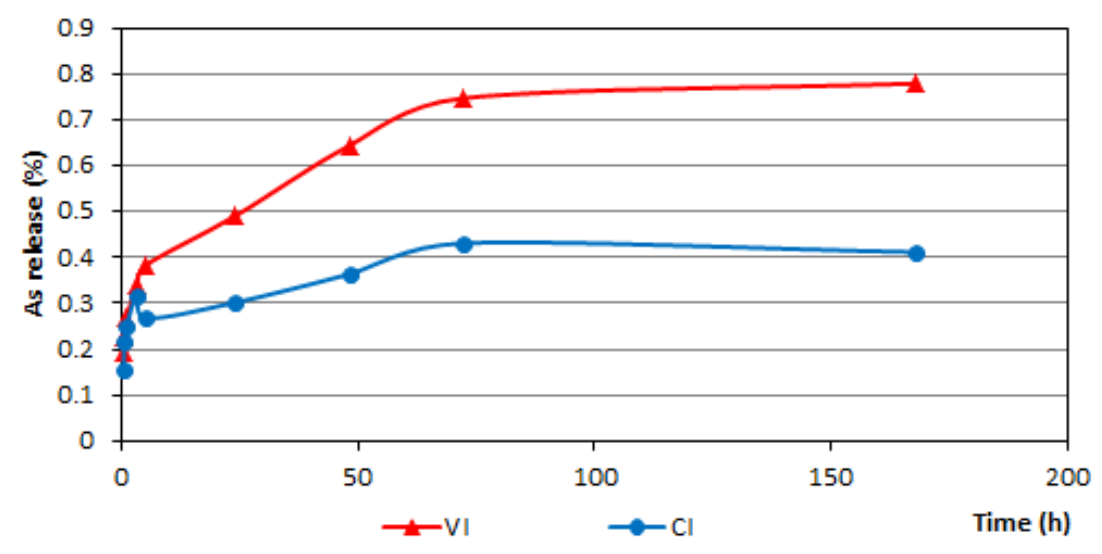

Figure 10. Percentage of arsenic released during leaching tests on one sample of Vico (VI) and one sample of Cimino (CI) rocks (initial arsenic content of both rock samples is about $30 \mathrm{mg} / \mathrm{kg})$.

The leaching tests were performed using deionized water as in other literature papers simulating water-rock or soil-water interactions [43-45,50,51] and also the effect of infiltration [52]. The use of real groundwater of the investigated area was not suitable, because its arsenic content (result of different factors including the natural rock-water interaction) would alter the study of the desorption/leaching behaviour we were investigating, as demonstrated by the results (not showed here) of preliminary tests performed for the choice of the experimental conditions. Other leaching solutions, often used to distinguish different fractions of the elements (e.g., exchangeable, bound to metal-oxides/organic matter, etc.) in soil or sediments ([53] and references therein) or to test different environmental conditions $[54,55]$ were as well considered unsuitable to simulate the real groundwater for the scopes of this study.

Finely ground samples were used for leaching tests for the following reasons: (1) to obtain a homogenous material for better experimental results in terms of both repeatability and accuracy; and 
(2) it is known [56] that there is a relation between sample particle size and amount of leached element, the latter increases as the particle sizes decrease, due to the higher specific surface area in contact with the extractant. As underlined elsewhere in the text, the length of the flow path and the different porosity seem to influence the arsenic content in groundwater, being the latter higher for longer times and higher porosities. Since the residence time characterizing the examined aquifer can not be reproduced in laboratory experiments, the use of fine particles aims at offsetting the relatively short contact time with an enhanced contact between water and particles surface, increasing the chemical reactivity of the rock samples.

\section{Discussion}

The data of the present study give new information on arsenic contents of the rocks of the Cimino and Vico volcanics. While data are available on arsenic concentrations of other Italian volcanic rocks, no known data yet existed on arsenic in the Cimino and Vico rocks, despite the great importance of that contaminant in this area. Average arsenic values measured in the rocks of the Cimino and Vico volcanic complexes are $27 \mathrm{mg} / \mathrm{kg}$ and $61 \mathrm{mg} / \mathrm{kg}$, respectively, with maximum values of $42 \mathrm{mg} / \mathrm{kg}$ and $166 \mathrm{mg} / \mathrm{kg}$, much higher than reported for other volcanic rocks in Italy. In fact, for the volcanoes of Southern Italy, values of about $1 \mathrm{mg} / \mathrm{kg}$ are reported for hawaiite lavas of Etna, and mean values of $9 \mathrm{mg} / \mathrm{kg}$ and $12 \mathrm{mg} / \mathrm{kg}$ are reported for the potassic volcanics of Vulcano Island and Vesuvius, respectively [7,57-59].

The presence of high concentrations of arsenic and other potentially toxic elements $[54,60]$ in the volcanic rocks of the area, as well as in the whole Roman Comagmatic Province (RCP) is attributed to the enrichment of incompatible element during the final stages of rock formation and to a diffuse percolation of fluids through the crust. This occurrence is widespread over the RCP and, particularly, Vico area as several gas emissions and intense hydrothermal activity highlight $[39,61]$.

Given the high arsenic concentrations measured in the rock samples of the Cimino and Vico volcanics, the role of the water-rock interaction in determining the high content of arsenic in groundwater can not be disregarded. Therefore, a preliminary evaluation of the eventual arsenic release due to water-rock interaction has been performed.

Based on the leaching tests, release of arsenic from the studied rocks seems to be very low, however, for $\mathrm{VI}$ it is twice than for $\mathrm{CI}$ rocks (about $0.8 \%$ and $0.4 \%$ of total arsenic content in the rocks for VI and CI, respectively). Moreover, even if the VI and CI rock samples used for the leaching test have the same initial arsenic content (about $30 \mathrm{mg} / \mathrm{kg}$ ), generally the measured total concentrations are higher for VI rocks. Consistently, we can assume that relatively higher release percentages from rocks with higher arsenic content result in higher total amounts of arsenic in terms of concentration in water that is actually the case of VI groundwater. An elevated arsenic content in rocks can thus be considered as a key factor causing high arsenic concentrations in groundwater, nevertheless the very low percentages of released arsenic measured do not allow to assume that this is the main factor. A combination of multiple causes, such as the dissolution of the volcanic glass component in the aquifer rock, desorption from mineral surface sites, and interaction of groundwater of the basal aquifer with thermal waters and/or associated mineralized zones (e.g., sulfide mineral oxidation) have been reported $[6,62]$ as mechanisms of arsenic release into groundwater. 
By examining the distribution of arsenic in groundwater in relation to the classes of aquifer, the lower values of arsenic observed for waters circulating in the Cimino complex and the higher values in waters of the Vico complex (Figure 5) can be interpreted as the result of both water interaction with rocks that differ in their arsenic contents and the different hydrogeological properties of the aquifers. In fact, it should be kept in mind that the VI aquifer, in addition to having a higher whole rock arsenic content, constitutes a thick and large aquifer with both primary and secondary porosity and is affected by intense hydrothermal activity. On the contrary, in the CI and LD aquifers of the Cimino complex groundwater mainly flows in fissures. Therefore, in the Cimino complex water-rock interaction probably takes place over shorter times due to a medium with higher transmissivity and lower storage capacity if compared with the VI aquifer, where primary and secondary porosity surely implies a higher storage capacity of the aquifer (Table 1). On the other hand, the significant content of arsenic in the LFV aquifer, also characterized by flow in fissures, and in the NWV aquifer (Vico complex) could be related to the rock composition (Figure 6).

Additional elements concerning the occurrence of arsenic in groundwater can be derived by means of comparing the hydrogeological model of the system (Figure 2) and the distribution of the contaminant in groundwater in the basal aquifer (Figures 8 and 9). The highest values are in an area elongated in a NW-SE direction, and can be explained through the complexity of the hydrostratigraphy and structural setting of the area and the related mixing phenomena occurring between water circulating in the basal volcanic aquifer and the fluids rising from depth that characterize the active hydrothermal system (Figure 3). This is in agreement with previous studies [12,17,18] and with maps of heat flow anomaly [21] and neotectonic and volcano-tectonic structures [28,31,32]. What arises from the present study by relating the content of arsenic in groundwater with the nature of the saturated basal aquifer is that in the NW-SE areas groundwater flow occurs mainly into the Vico volcanics, as was highlighted by the analysis of the potentiometric morphology and of the saturated aquifer (Figure 2a,b). In contrast, values of arsenic lower than $10 \mu \mathrm{g} / \mathrm{L}$ are found mainly in groundwater of the NE sector of the basal aquifer (Figures 8 and 9) where thermal fluids have no influence and groundwater mainly flows in the Cimino rocks (Figure $2 b$ ) in proximity to the potentiometric height (Figure 2a). In other words, in this area groundwater flow is independent from that in the other sectors of the system; it has higher flow velocity due to the fissured nature of the medium and it occurs in rocks that have lower arsenic content.

As expected, the coexistence of rocks with slow kinetics of arsenic release and short residence time of groundwater generates relatively low arsenic concentrations, as reported in other regions of the world (e.g., [63]). The influence of residence time on arsenic content of sampled groundwater is clear from the comparison between the distribution in the basal aquifer and in the perched aquifers or dome-impounded groundwater (Figure 4): in the entire hydrogeological system, the lowest arsenic contents were found in the sources, mainly springs located at high elevation, where the short flow path from recharge to discharge area implies a reduced water-rock interaction (Figure 3).

Based on the results arising from the relationship among arsenic content in rocks, hydrogeological properties of the different aquifers and distribution of the element in groundwater, an area of about $180 \mathrm{~km}^{2}$ has been recognized in the NE sector of the system, corresponding to the Cimino volcanics, where arsenic content in groundwater is generally lower than $10 \mu \mathrm{g} / \mathrm{L}$. Taking into account the lowest yield of the hydrogeological volcanic system, that is $5.7 \mathrm{~L} / \mathrm{s}$ per $\mathrm{km}^{2}$ [34], about $32 \times 10^{6} \mathrm{~m}^{3} / \mathrm{y}$ of 
groundwater suitable for human consumption results available. Even considering only $50 \%$ of this resource and taking into account groundwater dependent ecosystems, a sufficient safe drinking water amount for the needs of the local population (250 L/day for 170,000 inhabitants) is naturally available without resorting to expensive treatment plants scattered over the whole area. For these resources, a low fluoride content is also expected, another element that often exceeds the permissible value in the area concerned, fluoride being strongly correlated with arsenic [17]. Moreover, in the cold waters of the Cimino-Vico area, characterized by oxidizing conditions, the predominant species is the pentavalent $\mathrm{As}(\mathrm{V})$, which is mainly present as aqueous complex $\left(\mathrm{HAsO}_{4}{ }^{2-}\right.$ and $\left.\mathrm{H}_{2} \mathrm{AsO}_{4}{ }^{-}\right)$[12] and which represents the less toxic form of As.

Potential applications of this study can refer to the low arsenic content found in groundwater of the perched/dome-impounded aquifers. Those resources are currently not properly utilized for drinking water. Locations at high altitude and significant yield, compared to the number of residents, represent favorable conditions for tapping these aquifers by sub-horizontal boreholes (without the use of any electric pump) to supply small towns. Second potential application regards the tapping of groundwater from the basal aquifer in the NE sector, where probability to intercept water with arsenic content below $10 \mu \mathrm{g} / \mathrm{L}$ is high. The results of this study suggest that drawdown induced by the pumping wells should be limited, so that predominantly the faster circuits are captured. This can be performed in three ways: (1) locating new wells in the most transmissive zones of the fissured Cimino aquifer, (2) using partially penetrating wells with pumping rate designed to increase the maximum horizontal extent of the capture surface at the top of the aquifer [64], and (3) using well pumping at constant head that avoids the capture of the deeper and longer groundwater circuits, maintaining a water quality constant over time [65].

\section{Conclusions}

Our analysis of the Cimino-Vico volcanic region indicates that it contains a complex groundwater circulation system, including a continuous basal aquifer, discontinuous perched aquifers, groundwater flows at high altitude, and local influence of an active thermal system. Similar and equally complex circulation systems are typical of volcanic regions in Italy [9] and other regions of the world [66]. The occurrence of arsenic in groundwater is strongly affected by the composition and hydraulic properties of the different aquifers, in addition to the already known interaction with the rise of thermal fluids. Our findings highlight that the length of flow path, the residence time of groundwater, and the difference in arsenic content between the relatively acidic rocks of the Cimino complex and the alkaline rocks of the Vico complex, as well as their different leaching behavior, have a significant influence on arsenic concentrations in groundwater (range in present study is $0.1 \mu \mathrm{g} / \mathrm{L}$ to $150 \mu \mathrm{g} / \mathrm{L}$ ).

By interpreting the distribution and mobility of arsenic in water and rocks and the hydrogeology of the system it has been possible to identify sufficient water resources with arsenic concentrations that are suitably low for supplying drinking water to the region. Specifically, both waters of the basal aquifer in the NE sector of the system constituted by fissured rocks of the Cimino complex, and those flowing at high altitude in the lava domes of the same complex, have arsenic contents lower than 10 $\mu \mathrm{g} / \mathrm{L}$, the present limit for drinking water quality. At present, withdrawal supplying drinking water mainly taps the basal aquifer in the sectors with arsenic concentration over $10 \mu \mathrm{g} / \mathrm{L}$, and the only 
implemented actions to meet current drinking water standards, and overcome emergencies that have already occurred, are construction of numerous expensive plants for the treatment of the contaminated waters. We believe that a truly integrated approach, as that used in this study case, is essential for promoting sustainable water management in the volcanic areas, which typically include more groundwater flow paths interacting with rocks different in composition and hydraulic properties.

\section{Acknowledgments}

The authors thank Talete SpA and ARPA Lazio for providing several water analyses and for their support at the well and springs locations.

The doctoral grant of Maurizio Mazzuoli has been partially financed by ENEA through the funds raised under the law "Decree of the President of the Council of 20/01/2006" and in the framework of the ENEA project "Geochemical features of Northern Latium: high natural concentration of potentially toxic elements".

The authors wish to thank Todd K. Hinkley, who has significantly improved the text and the content of the manuscript with his suggestions and critical review.

We are grateful to the three anonymous reviewers for their helpful comments on this manuscript.

\section{Author Contributions}

Vincenzo Piscopo and Carlo Cremisini conceived and designed the experiments. Maurizio Mazzuoli, Elisa Nardi, Marco Proposito and Cinzia Crovato performed the experiments. Maurizio Mazzuoli, Elisa Nardi, Marco Proposito analyzed and elaborated geochemical data. Antonella Baiocchi and Francesca Lotti elaborated GIS and geostatistical data. Luca Lucentini and Enrico Veschetti contributed data on water samples. Giovanna Armiento, Francesca Lotti, Maurizio Mazzuoli and Vincenzo Piscopo wrote the paper. All the authors contributed to the interpretation and discussion of the results.

\section{Conflicts of Interest}

The authors declare no conflict of interest.

\section{References}

1. Ballantyne, J.M.; Moore, J.N. Arsenic geochemistry in geothermal systems. Geochim. Cosmochim. Acta 1988, 52, 475-483.

2. Hinkley, T.K.; Lamothe, P.J.; Wilson, S.A.; Finnegan, D.L.; Gerlach, T.M. Metal emissions from Kilauea, and a suggested revision of the estimated worldwide metal output by quiescent degassing of volcanoes. Earth Planet. Sci. Lett. 1999, 170, 315-325.

3. Smedley, P.L.; Kinniburgh, D.G. A review of the source, behaviour and distribution of arsenic in natural waters. Appl. Geochem. 2002, 17, 517-568.

4. Webster, J.G.; Nordstrom, D.K. Geothermal Arsenic. In Arsenic in Ground Water, Geochemistry and Occurrence; Welch, A.H., Stollenwerk, K.G., Eds.; Kluwer Academic Publichers: Dordrecht, The Netherlands, 2003; pp. 101-125. 
5. Achene, L.; Ferretti, E.; Lucentini, L.; Pettine, P.; Veschetti, E.; Ottaviani, M. Arsenic content in drinking-water supplies of an important volcanic aquifer in central Italy. Toxicol. Environ. Chem. 2010, 92, 509-520.

6. Aiuppa, A.; Avino, R.; Brusca, L.; Caliro, S.; Chiodini, G.; D’Alessandro, W.; Favara, R.; Federico, C.; Ginevra, W.; Inguaggiato, S.; et al. Mineral control of arsenic content in thermal waters from volcano-hosted hydrothermal systems: Insights from Island of Ischia and Phlegrean Fields (Campanian Volcanic Province, Italy). Chem. Geol. 2006, 229, 313-330.

7. Aiuppa, A.; D’Alessandro, W.; Federico, C.; Palumbo, B.; Valenza, M. The aquatic geochemistry of arsenic in volcanic groundwaters from southern Italy. Appl. Geochem. 2003, 18, 1283-1296.

8. Aiuppa, A.; Allard, P.; D’Alessandro, W.; Michel, A.; Parello, F.; Treuil, M.; Valenza, M. Mobility and fluxes of major, minor and trace metals during basalt weathering at Mt. Etna volcano (Sicily). Geochim. Cosmochim. Acta 2000, 64, 1827-1841.

9. Baiocchi, A.; Lotti, F.; Piscopo, V. Influence of hydrogeological setting on the arsenic occurrence in groundwater of the volcanic areas of central and southern Italy. AQUA Mundi 2011, 2, 131-142.

10. Brondi, M.; Dall'Aglio, M.; Ghiara, E. Elementi in traccia di interesse geochimico e tossicologico nei fluidi termali e geotermici dei Campi Flegrei e di Larderello. Acqua Aria 1986, 10, 1102-1111.

11. Celico, P.; Dall'Aglio, M.; Ghiara, M.R.; Stanzione, D.; Brondi, M.; Prosperi, M. Geochemical monitoring of the thermal fluids in the Phlegraean Fields from 1970 to 1990. Boll. Soc. Geol. Ital. 1992, 111, 409-422.

12. Cinti, D.; Poncia, P.P.; Brusca, L.; Tassi, F.; Quattrocchi, F.; Vaselli, O. Spatial distribution of arsenic, uranium and vanadium in the volcanic-sedimentary aquifers of the Vicano-Cimino Volcanic District (Central Italy). J. Geochem. Explor. 2015, 152, 123-133.

13. Cremisini, C.; Dall'Aglio, M.; Ghiara, E. Arsenic in Italian rivers and in some cold and thermal spring. In Proceedings of the International Conference on Management and Control of Heavy Metals in the Environment, London, UK, 18-21 September 1979; pp. 341-344.

14. Dall'Aglio, M. Problemi emergenti di Geochimica Ambientale e Salute in Italia con Particolare Riferimento all'arsenico. In 2' Convegno Nazionale Sulla Protezione e Gestione delle Acque Sotterranee; Quad Geol Appl, Pitagora Ed.: Bologna, Itlay, 1996; pp. 85-95.

15. Lima, A.; Cicchella, D.; Di Francia, S. Natural contribution of harmful elements in thermal groundwaters of Ischia Island (southern Italy). Environ. Geol. 2003, 43, 930-940.

16. Vivona, R.; Preziosi, E.; Madé, B.; Giuliano, G. Occurrence of minor toxic elements in volcanic-sedimentary aquifers: A case study in central Italy. Hydrogeol. J. 2007, 15, 1183-1196.

17. Angelone, M.; Cremisini, C.; Piscopo, V.; Proposito, M.; Spaziani, F. Influence of hydrostratigraphy and structural setting on the arsenic occurrence in groundwater of the Cimino-Vico volcanic area (Central Italy). Hydrogeol. J. 2009, 17, 901-914.

18. Baiocchi, A.; Coletta, A.; Espositi, L.; Lotti, F.; Piscopo, V. Sustainable groundwater development in a naturally arsenic-contaminated aquifer: The case of the Cimino-Vico volcanic area (Central Italy). Ital. J. Eng. Geol. Environ. 2013, 1, 5-18.

19. Smedley, P.L.; Nicolli, H.B.; Macdonald, D.M.J.; Barros, A.J.; Tullio, J.O. Hydrogeochemistry of arsenic and other inorganic constituents in groundwaters from La Pampa, Argentina. Appl. Geochem. 2002, 17, 259-284. 
20. Aloupi, M.; Angelidis, M.; Gavriil, A.; Koulousaris, M.; Varnavas, S. Influence of geology on arsenic concentrations in ground and surface water in central Lesvos, Greece. Environ. Monit. Assess. 2009, 151, 383-396.

21. Cataldi, R.; Mongelli, F.; Squarci, P.; Taffi, L.; Zito, G.; Calore, C. Geothermal ranking of Italian territory. Geothermics 1995, 24, 115-129.

22. Lardini, D.; Nappi, G. I cicli eruttivi del complesso vulcanico cimino. Rend. Soc. Ital. Mineral. Petrol. 1987, 42, 141-153.

23. Sollevanti, F. Geologic, volcanologic and tectonic setting of the Vico-Cimino area, Italy. J. Volcanol. Geotherm. Res. 1983, 17, 203-217.

24. Villa, I.M. Datazioni ${ }^{39} \mathrm{Ar} /{ }^{40} \mathrm{Ar}$ delle basi delle vulcaniti della Provincia Romana. Rend. Soc. Ital. Mineral. Petrol. 1987, 42, 315.

25. Bertagnini, A.; Sbrana, A. II vulcano di Vico: Stratigrafia del complesso vulcanico e sequenze eruttive delle formazioni piroclastiche. Mem. Soc. Geol. Ital. 1986, 35, 699-713.

26. Locardi, E. Tipi di ignimbrite di magmi mediterranei Le ignimbriti del vulcano di Vico. Atti Soc. Tosc. Sci. Nat. 1965, 72, 53-173.

27. Mattias, P.P.; Ventriglia, V. La regione vulcanica dei Monti Cimini e Sabatini. Mem. Soc. Geol. It. 1970, 9, 331-384.

28. Baldi, P.; Decandia, F.A.; Lazzarotto, A.; Calamai, A. Studio geologico del substrato della copertura vulcanica laziale nella zona dei laghi di Bolsena, Vico e Bracciano. Mem. Soc. Geol. Ital. 1974, 13, 575-606.

29. Buonasorte, G.; Carboni, M.G.; Conti, M.A. Il substrato plio-pleistocenico delle vulcaniti sabatine: Considerazioni stratigrafiche e paleoambientali. Boll. Soc. Geol. Ital. 1991, 110, 35-40.

30. Funiciello, R.; Locardi, E.; Lombardi, G.; Parotto, M. The main volcanic groups of Latium Relations between structural evolution and petrogenesis. Geol. Romana 1977, 15, 279-300.

31. La Torre, P.; Nannini, R.; Sollevanti, F. Geothermal exploration in central Italy: Geophysical survey in Cimini Range area. In Proceedings of 43rd Meeting European Association Exploration Geophysic, Venezia, Italy, 26-29 May 1981; pp. 1-24.

32. Barberi, F.; Buonasorte, G.; Cioni, R.; Fiordelisi, A.; Foresi, L.; Iaccarino, S.; Laurenzi M.A.; Sbrana, A.; Vernia, L.; Villa I.M. Plio-Pleistocene geological evolution of the geothermal area of Tuscany and Latium. Mem. Descr. Carta Geol. Ital. 1994, 49, 77-134.

33. Buonasorte, G.; Fiordelisi, A.; Pandeli, E.; Rossi, U.; Sollevanti, E. Stratigraphic correlations and structural setting of the pre-neoautochtonous sedimentary sequences of northern Latium. Period. Mineral. 1987, 56, 111-122.

34. Baiocchi, A.; Dragoni, W.; Lotti, F.; Luzzi, G.; Piscopo, V. Outline of the hydrogeology of the Cimino and Vico volcanic area and of the interaction between groundwater and Lake Vico (Lazio Region, Central Italy). Boll. Soc. Geol. Ital. 2006, 125, 187-202.

35. Baiocchi, A.; Barbieri, M.; Battistel, M.; Delfanti, L.M.P.; Lotti, F.; Madonna, S.; Piscopo, V. The role of perched aquifers and dome-impounded groundwater in drinking water supply in the Cimino-Vico volcanoes (Central Italy). In Proceedings of Flowpath 2014, National Meeting on Hydrogeology, Viterbo, Italy, 18-20 June 2014; Baiocchi, A., Lotti, F., Onofri, S., Piscopo, V., Eds.; Dipartimento di Scienze Ecologiche e Biologiche: Viterbo, Italy, 2014; pp. 40-41. 
36. Baiocchi, A.; Lotti, F.; Piscopo, V. Conceptual hydrogeological model and groundwater resource estimation in a complex hydrothermal area: The case of the Viterbo geothermal area (Central Italy). J. Water Res. Prot. 2012, 4, 231-247.

37. Baiocchi, A.; Lotti, F.; Piscopo, V. Impact of groundwater withdrawals on the interactions between overlapping aquifers in the Viterbo geothermal area (Central Italy). Hydrogeol. J. 2013, 21, 1339-1353.

38. Piscopo, V.; Barbieri, M.; Monetti, V.; Pagano, G.; Pistoni, S.; Ruggi, E.; Stanzione, D. Hydrogeology of thermal waters in Viterbo area, central Italy. Hydrogeol. J. 2006, 14, 1508-1521.

39. Cinti, D.; Tassi, F.; Procesi, M.; Bonini, M.; Capecchiacci, F.; Voltattorni, N.; Vaselli, O.; Quattrocchi, F. Fluid geochemistry and geothermometry in the unexploited geothermal field of the Vicano-Cimino Volcanic District (Central Italy). Chem. Geol. 2014, 371, 96-114.

40. ISPRA 2010. Archivio storico delle indagini, Legge 464/84. Available online: http://sgi.isprambiente.it/GMV2 (accessed on 25 July 2015).

41. Capelli, G.; Mazza, R.; Gazzetti, C. Strumenti e Strategie per la Tutela e l'uso Compatibile della Risorsa Idrica nel Lazio-Gli Acquiferi Vulcanici; Pitagora: Bologna, Italy, 2005.

42. Method 3052-Microwave Assisted Acid Digestion of Siliceous and Organically Based Matrices (SW-846). 1996. Available online: http://www.epa.gov/wastes/hazard/testmethods/sw846/pdfs/ 3052.pdf (accessed on 30 July 2015).

43. Ruggieri, F.; Marìn, V.; Gimeno, D.; Fernandez-Turiel, J.L.; Garcìa-Valles, M.; Gutierrez, L. Application of zeolitic volcanic rocks for arsenic removal from water. Eng. Geol. 2008, 101, 245-250.

44. Ruggieri, F.; Fernandez-Turiel, J.L.; Saavedra, J.; Gimeno, D.; Polanco, E.; Naranjo, J.A. Environmental geochemistry of recent volcanic ashes from the Southern Andes. Environ. Chem. 2011, 8, 236-247.

45. Tabelin, C.B.; Hashimoto, A.; Igarashi, T.; Yoneda, T. Leaching of boron, arsenic and selenium from sedimentary rocks: I. effects of contact time, mixing speed and liquid-to-solid ratio. Sci. Total Environ. 2014, 472, 620-629.

46. Matheron, G. Principles of geostatistics. Economic. Geol. 1963, 58, 1246-1266.

47. Rivoirard, J. Introduction to Disjunctive Kriging and Non-Linear Geostatistics; Oxford University Press: Oxford, UK, 1994.

48. Webster, R. Local disjunctive kriging of soil properties with change of support. Eur. J. Soil Sci. 1991, 42, 301-318.

49. EUR-Lex Access to European Union Law. Council Directive 98/83/EC of 3 November 1998 on the quality of water intended for human consumption. Available online: http://eur-lex.europa.eu/ legal-content/EN/ALL/?uri=CELEX:31998L0083 (accessed on 26 July 2015).

50. Bianchini, G.; Di Giuseppe, D.; Antisari, L.V. Soil-water interaction in soils of the Po River Plain (Ferrara, Northern Italy): Insights on heavy-metal mobility and phytoavailability. Period. Mineral. 2013, 82, 163-176.

51. Carbone, C.; Dinelli, E.; Marescotti, P.; Gasparotto, G.; Lucchetti, G. The role of AMD secondary minerals in controlling environmental pollution: Indications from bulk leaching tests. J. Geochem. Explor. 2013, 132, 188-200.

52. Noubactep, C.; Chen-Braucher, D.; Schlothauer, T. Arsenic release from a natural rock under near-natural oxidizing conditions. Eng. Life Sci. 2008, 8, 622-630. 
53. Rao, C.R.M.; Sahuquillo, A.; Lopez Sanchez, J.F. A review of the different methods applied in environmental geochemistry for single and sequential extraction of trace elements in soils and related materials. Water Air Soil Pollut. 2008, 189, 291-333.

54. Armiento, G.; Bellatreccia, F.; Cremisini, C.; Della Ventura, G.; Nardi, E.; Pacifico, R. Beryllium natural background concentration and mobility: A reappraisal examining the case of high Be-bearing pyroclastic rocks. Environ. Monit. Assess. 2012, 185, 559-572.

55. Mazziotti-Tagliani, S.; Angelone, M.; Armiento, G.; Pacifico, R.; Cremisini, C.; Gianfagna, A. Arsenic and fluorine in the Etnean volcanics from Biancavilla, Sicily, Italy: Environmental implications. Environ. Earth Sci. 2012, 66, 561-572.

56. Tamoto, S.; Yoshihiko, I.; Shoji, H. The leaching characteristic of heavy metals from altered volcanic rocks of several grain sizes in Hokkaido, northern Japan. In Proceedings of the International Symposium “Geoline 2005”, Lyon, France, 23-25 May 2005.

57. Allard, P.; Aiuppa, A.; Loyer, H.; Carrot, F.; Gaudry, A.; Pinte, G.; Michel, A.; Dongarrà, G. Emission rate of metals and acid gases during long-lived Basalt degassing at Stromboli volcano. J. Res. Lett. 2000, 27, 1207-1210.

58. Ayuso, R.A.; De Vivo, B.; Rolandi, G.; Seal II, R.R.; Paone, A. Geochemical and isotopic $(\mathrm{Nd}-\mathrm{Pb}-\mathrm{Sr}-\mathrm{O})$ variation bearing on the genesis of volcanic rocks from Vesuvius, Italy. J. Volcanol. Geotherm. Res. 1998, 82, 53-78.

59. Paone, A.; Ayuso, R.A.; de Vivo, B. A metallogenic survey of alkalic rocks of Mt. Somma-Vesuvius volcano. Mineral. Petrol. 2001, 73, 201-233.

60. Armiento, G.; Angelone, M.; De Cassan, M.; Nardi, E.; Proposito, M.; Cremisini, C. Uranium natural levels in water and soils: Assessment of the Italian situation in relation to quality standards for drinking water. Rend. Lincei 2015, doi:10.1007/s12210-015-0462-x.

61. Villemant, B.; Fléhoc, C. U-Th fractionation in K-rich magma genesis: The Vico volcano, Central Italy. Earth Planet. Sci. Lett. 1989, 91, 312-326.

62. Johannesson, K.H.; Tang, J. Conservative behavior of arsenic and other oxyanion-forming trace elements in an oxic groundwater flow system. J. Hydrol. 2009, 378, 13-28.

63. Ayotte, J.D.; Nolan, B.T.; Nuckols, J.R.; Cantor, K.P.; Robinson, G.R.; Baris, D.; Hayes, L.; Karagas, M.; Bress, W.; Silverman, D.T.; et al. Modeling the probability of arsenic in groundwater in New England as a tool for exposure assessment. Environ. Sci. Technol. 2006, 40, 3578-3585.

64. Faybishenko, B.A.; Javandel, I.; Witherspoon, P.A. Hydrodynamics of the capture zone of a partially penetrating well in a confined aquifer. Water Resour. Res. 1995, 31, 859-866.

65. Piscopo, V.; Summa, G. Experiment of pumping at constant-head: An alternative possibility to the sustainable yield of a well. Hydrogeol. J. 2007, 15, 679-687.

66. Custodio, E. Groundwater in volcanic rocks. In Groundwater in Fractured Rocks; Krasny, J., Sharp, J.M., Eds.; Taylor \& Francis: London, UK, 2007; pp. 95-104.

(C) 2015 by the authors; licensee MDPI, Basel, Switzerland. This article is an open access article distributed under the terms and conditions of the Creative Commons Attribution license (http://creativecommons.org/licenses/by/4.0/). 